\title{
Inflation Targeting in Turkey
}

\author{
Fazıl Kayıkçı, Sümeyye Kaplan \\ Department of Economics, Yıldız Technical University, İstanbul, Turkey \\ Email: fkayikci@yildiz.edu.tr, kaplansumeyye@gmail.com
}

How to cite this paper: Kayıkçı, F. and Kaplan, S. (2019) Inflation Targeting in Turkey. Theoretical Economics Letters, 9, 2217-2228.

https://doi.org/10.4236/tel.2019.97140

Received: August 8, 2019

Accepted: August 27, 2019

Published: August 30, 2019

Copyright $\odot 2019$ by author(s) and Scientific Research Publishing Inc. This work is licensed under the Creative Commons Attribution International License (CC BY 4.0).

http://creativecommons.org/licenses/by/4.0/

\section{c) (i) Open Access}

\begin{abstract}
Inflation targeting strategy has emerged as the result of new pursuits and researches actualized due to insufficiency of monetary policies-implemented for price stability by the central banks until 1990s-in reaching the required consequences in both developed and developing countries, and this strategy had initially been implemented in New Zealand. As this strategy has indicated a successful performance since its implementation, it has become a targeting strategy that many countries struggling with high inflation-including Turkey-prefer and put into practice. In this study, the inflation targeting policy's conformity to country's economic cycle, its success, and its effect on macroeconomic factors were analyzed via the model formed by the use of GDP, exchange rate, CPI, interest rate, output gap, and crude oil prices. Inflation targeting regime was examined for the period of 1996:1-2018:4 via the VAR Model, Granger Causality Test, and action-reaction analyses. The results obtained have indicated the presence of expectation and cost inflation, and that it is triggering the inflation. Moreover, it has been observed that inability to reach the targeted value, and inclining trend of inflation are causing uncertainty of inflation.
\end{abstract}

\section{Keywords}

Macroeconomics, Monetary Policy, Inflation Targeting

\section{Introduction}

With the oil crisis in the 1970s and the collapse of the Bretton Woods system, global inflation has shaken the economies deeply. For this reason, monetary authorities have implemented monetary targeting, interest rate targeting and exchange rate targeting strategies in order to achieve price stability, but they have not achieved the desired success from these strategies. Inflation targeting strategy was first introduced in New Zealand in 1990, when price stability based on the New Neoclassical Synthesis Theory was considered as the main objective due 
to the failure of other monetary policies in such a period. Other countries struggling with high inflation have started to use this strategy as it has achieved successful results in the countries where it is implemented. The most important features of inflation targeting strategy are the fact that the central bank is independent at the point of choosing the instruments to be used in the management of monetary policy, has a transparent structure and has the obligation to account due to its independence.

Implicit inflation targeting strategy was implemented in Turkey between the years 2002-2005, and explicit inflation targeting strategy began to be implemented literally since 2006. Inflation target is determined as the collective decision of the Central Bank and the Government. In order to provide the necessary prerequisites to be successful in this strategy and to transform it into a structure that is compatible with the conditions of the country, the Central Bank gradually switched to this policy. For this reason, this strategy, started to be implemented explicitly since 2006, when the necessary conditions were met. However, the central bank, which achieved quite successful results in the implicit inflation targeting period, failed to achieve the same success in the open inflation targeting period. Targets have always deviated except 2009-2010. This led to a questioning of the success of the strategy and reduced the confidence in the Central Bank Republic of Turkey (CBRT). In the light of all these developments, the questions sought in this study are as follows;

- Is Inflation Targeting Strategy a suitable policy for Turkey's economic conjuncture? And was it successful in Turkey?

- What was the effect of the Inflation Targeting Strategy on the other macroeconomic factors?

There exist numerous studies and econometric analysis in the literature about inflation targeting in Turkey. In the econometric analysis, VAR method was applied mostly, but there were also other studies which apply different methods such as OLS method and AR Model. For example; [1] and [2] the effect of inflation targeting strategy on inflation and growth; [3], forecasting in inflation targeting strategy; [4] [5] [6] analyzed the performance of inflation targeting strategy on macroeconomic variables by VAR model, while [7] and [8] analyzed the effect of inflation targeting strategy on macroeconomic variables by using OLS method. [9] used AR model; [10] investigated the Pooled Regression Model.

This study analyzes the relationship between inflation targeting strategy and some macroeconomic variables in Turkey. It also examines the relationship between price stability and economic stability by using VAR method. This study consists of four sections. After introduction, information about the process and the post-implementation period leading to the implementation of the inflation targeting strategy is presented in the second section, the methodology section shows the findings obtained in the empirical study is explained in the third section and finally, last section concludes. 


\section{Inflation Targeting Process in Turkey}

After the 2001 crisis, the Central Bank announced that it would adopt an inflation targeting strategy in 2002 which was implemented successfully in some other countries. Accordingly, in order to move to the main target, it started to follow the implicit inflation targeting strategy in 2002-2005 periods. The objective of this implicit inflation period, which is implemented by the CBRT in order to adopt the inflation targeting strategy at certain stages rather than directly, is to provide the prerequisites deemed necessary in the inflation targeting strategy and to harmonize the monetary policy with this strategy. For this reason, the Central Bank announced on 2 January 2002 that the implicit inflation targeting period would be implemented until the conditions were met, and that the conditions would be passed to the explicit inflation targeting period. This strategy, which was first expressed by the Central Bank in 1999 with a letter of intent presented to the IMF on the monetary policies, prepared to cover the years 2000-2002, was hampered by the 2001 crisis and therefore a new letter of intent to the IMF on January 18, 2002 and targeted inflation rates for these years are $35 \%, 20 \%$ and $12 \%$, respectively [11].

With the implementation of this program by the Central Bank, significant and remarkable distances have been taken in order to meet the prerequisites, compliance with the floating exchange rate strategy has been expanded, the scope of the information set to be used in the strategy has been expanded, progress has been achieved in communication policies, financial fragility and the negative impacts have been weakened, reliability has been increased, institutional and technical infrastructure have been improved during this period. Moreover, increased transparency and improved forecasting methods for inflation are the other achievements of the program. In this period, inflation targets were determined together with the government, short-term interest rates were applied effectively to reach the targeted inflation rate, and the monetary base was used to serve as an additional anchor and the monetary base targets were also used in line with the inflation targets. In 2005, 6 zeros were taken from the local currency "Turkish Lira" and the transition to the "New Turkish Lira" was made and a monetary reform step was taken. A significant progress has been made in terms of the independence of the central bank and strong expectations that inflationary processes will not be experienced again. All of these are the structural implementations realized during the implicit inflation period which we call the transition period [12].

In the 2002-2005 implicit inflation targeting strategy, the Central Bank decided that the necessary prerequisites were met due to the success achieved in the fight against inflation. Within the scope of the explicit inflation targeting strategy, the central bank uses the short-term repo rate as the policy rate to intervene in the market for reaching the inflation target. The index used for this strategy is the Index of Special Consumer Price Index (CPI). Inflation targets are set with the government and announced with a three-year target horizon. A con- 
fidence interval of 2 points was determined with the point up and down around the target. If the inflation target cannot be met and the possibility of such an event, the central bank is responsible for explaining the reasons for this situation and the measures to be taken for its transparency and accountability to the Government and the public. Unlike the implicit inflation targeting period, decisions regarding interest rates are taken by voting at the Monetary Policy Committee (MPC) and announced on the same day after the meeting with the reasons. So with this period, MPC moves to decision-making position rather than giving advice.

In the period in which the explicit inflation targeting policy started to be implemented, deviations and volatilities occurred in the inflation target, especially due to external factors outside the monetary policy, in which the monetary authority could not control. Capital outflows from developing countries, increase in the price of oil and the Mortgage Crisis occurred in the US in 2008 turned into a global crisis affecting the entire world. Since Turkey is an oil importer developing country, these factors created upward trend in inflation rates in Turkey and deviations occurred from the target. Inflation rates in 2009 and 2010, which were lower than the target after the 2008 Financial Crisis, were due to the decrease in production and decreasing demand in the world [13].

At the end of 2010, the CBRT introduced a new monetary strategy that could respond to external shocks to weaken the deteriorating impact of the global financial crisis. In this new strategy, the central bank has introduced a new policy approach that considers financial stability as well as price stability. Accordingly, in its new strategy, the central bank has introduced an asymmetric and wide corridor system and a flexible system in which multiple interest rates based on active liquidity policy are used as instruments. The broad interest rate corridor implemented by the central bank makes a significant contribution to monetary policy by reducing the negative impact of fluctuations in capital movements during periods of global turmoil, but has some difficulties in understanding the stance of monetary policy. In this context, in 2016, the central bank gradually lowered the upper band of the wide interest rate corridor, namely overnight borrowing interest rate by $2.5 \%$. Thus, the transition to a more easily understandable simple monetary policy is possible [14].

When the inflation rate reached two digits again during the 2008 crisis, the central bank raised the policy rate to $25.50 \%$ in order to ensure price stability. This increase in the interest rate that allows the flow of foreign capital to Turkey and thus inflation returned to single digits again. However, the Federal Reserve's increasing interest rates due to the effects of the 2008 crisis also caused the capital in the developing countries to flow into the developed countries. Turkey's borders are located around the war situation and the impact of political instability on the exchange rate for the year 2012 has started to increase the effects of this situation continuously. All these adversities caused a continuous increase in the inflation rate [13]. 


\section{Data and Methodology}

\subsection{Data}

Macroeconomic variables as CPI (TUFE), Nominal Exchange Rate (DOLAR), Interest Rate (FAIZ), Crude Oil Prices (PETROL) and Output Gap (CIKTI) were used for the period 1996:1-2018:4. The reason for starting from 1996 is due to the lack of data for the interest rate variable used in the analysis for the period before. Data for the variables to be used in this study were obtained from TURKSTAT. Stability test was applied to the data sets obtained in quarters and all of them were seasonally adjusted. The data in Turkish Lira has been translated into United States dollars and logarithm of all variables were used (Table $1)$.

\subsection{Methodology and Empirical Results}

In order to perform VAR analysis, the series has to be stationary. Therefore, first of all, unit root test was applied to see if they are stationary. Variables need to be seasonally adjusted before checking stability. The reason for this is that the effect of seasonal variations on both dependent and independent variables is different from each other with the extra mobility added by the seasonal variables. This leads to a negative effect of the variables added to the regression in reaching the accurate and accurate estimates [15]. Therefore, in this study, all variables were first seasonally adjusted by X12 method and then they were tested for stationary tests with Augmented Dickey-Fuller (ADF), Phillips Perron (PP) and Kwiatkowski Phillips Schmidt Shin (KPSS) tests. The results are shown in Table 2.

In ADF and PP tests, all variables were stable at $1 \%$ significance level. This means that they reject the Ho hypothesis and do not have a unit root. After determining the lag length, we try to find out the success of inflation targeting with

Table 1. Summary statistics of data.

\begin{tabular}{cccccc}
\hline & CIKTI & DOLAR & ENF & FAIZ & PETROL \\
\hline Mean & -0.003 & 0.014 & -0.001 & 0.002 & -0.003 \\
Median & 0.001 & 0.009 & 0.000 & 0.001 & 0.008 \\
Maximum & 0.052 & 0.107 & 1.543 & 0.173 & 0.150 \\
Minimum & -0.109 & -0.023 & -1.211 & -0.120 & -0.324 \\
Std, Dev. & 0.027 & 0.028 & 0.494 & 0.057 & 0.081 \\
Skewness & -1.352 & 1.435 & 0.406 & 0.374 & -1.429 \\
Kurtosis & 6.481 & 5.528 & 4.163 & 4.201 & 7.170 \\
Jarque-Bera & 38.045 & 28.654 & 3.941 & 3.921 & 50.048 \\
Probability & 0.000 & 0.000 & 0.139 & 0.141 & 0.000 \\
Sum & -0.164 & 0.676 & -0.048 & 0.096 & -0.156 \\
Sum Sq, Dev. & 0.035 & 0.037 & 1.124 & 0.147 & 0.299 \\
Observations & 47 & 47 & 47 & 47 & 47 \\
\hline
\end{tabular}


Table 2. Unit root test results.

\begin{tabular}{ccccccc}
\hline \multicolumn{2}{c}{ ADF } & \multicolumn{2}{c}{ PP } & \multicolumn{2}{c}{ KPSS } \\
\hline Variables & Trend-C & Constant & Trend-C & Constant & Trend-C & Constant \\
\hline TUFE & $-7.854^{* * *}$ & $-8.656^{* * *}$ & $-31.827^{* * *}$ & $-20.304^{* * *}$ & $0.179^{*}$ & $0.294^{* * *}$ \\
DOLAR & $-6.431^{* * *}$ & $-6.109^{* * *}$ & $-6.431^{* * *}$ & $-6.109^{* * *}$ & 0.311 & $0.576^{*}$ \\
FAIZ & $-4.426^{* * *}$ & $-4.349^{* * *}$ & $-4.312^{* * *}$ & $-4.214^{* *}$ & $0.206^{*}$ & $0.359^{* *}$ \\
PETROL & $-7.811^{* * *}$ & $-7.835^{* * *}$ & $-7.685^{* * *}$ & $-7.715^{* * *}$ & $0.064^{* *}$ & $0.104^{* * *}$ \\
CIKTI & $-7.982^{* * *}$ & $-7.826^{* * *}$ & $-8.0132^{* * *}$ & $-7.878^{* * *}$ & $0.143^{* *}$ & $0.242^{* * *}$ \\
\hline
\end{tabular}

Note: ${ }^{*}{ }^{* *}$ and ${ }^{* *}$ indicate the rejection of Null Hypothesis of unit root at the significance level of $10 \%, 5 \%$ and $1 \%$ respectively and shows that the series are stationary.

VAR model and the interaction between macroeconomic factors with Granger causality test. For this purpose, we created a regression model based on the variables we discussed above.

$$
\begin{aligned}
\operatorname{TUFE}_{T}= & C+\alpha_{1 i} \sum_{i=1}^{n} c a_{t-i}+\alpha_{2 i} \sum_{i=1}^{n} \mathrm{TUFE}_{t-i}+\alpha_{3 i} \sum_{i=1}^{n} \text { DOLAR }_{t-i} \\
& +\alpha_{4 i} \sum_{i=1}^{n} \mathrm{FAIZ}_{t-i}+\alpha_{5 i} \sum_{i=1}^{n} \mathrm{PETROL}_{t-i}+\alpha_{6 i} \sum_{i=1}^{n} \mathrm{CIKTI}_{t-i}+\varepsilon_{t}
\end{aligned}
$$

In this model, TUFE, DOLAR, FAIZ, PETROL and CIKTI are the vector of internal variables, $C$ is the constant term, $\alpha$ is the matrix of the coefficients to be estimated, and $\varepsilon_{t}$ is error term. The optimal lag length is determined according to the Likelihood Ratio "LR", Final Estimate Error "FPE", Akaike Information Criterion "AIC", Schwarz Information Criterion "SC" and Hannan-Quinn "HQ".

According to Table 3; the optimal lag length is 2 for FPE, AIC, HQ statistics, 1 for SC statistics, and 4 for LR test only. All of them were tested for a $5 \%$ level of significance. To determine the optimal lag length, we look at the Lagrange Multiplier (LM) test, which accounts for autocorrelation. Accordingly, is seen that there exists autocorrelation. However, in determining the lag length, there should be no autocorrelation and constant variance. In light of all this information, since the fourth lag length value contains autocorrelation the optimal lag length was determined as 2 . Also, according to the variance test we tried to examine, Chi-square $=323.26$ and $\mathrm{p}$-value is greater than all significance levels, H0 hypothesis is not rejected and it is seen that there is no variable variance and this model has a normal distribution.

Granger Causality Test is a method used to determine the direction of causality of the relationship between variables statistically. In Table 4, the direction of causality of the variables is given. Accordingly, the direction of causality between interest and output is from interest to output gap. In other words, interest is the cause of the output gap. The relationship between interest and dollar showed that causality is from interest to dollar. The causality in the relationship between CPI and dollar is from CPI to dollar. There was no bi-directional causality between these variables. If we look at the results of causality, each volatility in interest rate affects the output gap. In other words, increasing interest rates decreases the 
Table 3. Lag length selection criteria for VAR model.

\begin{tabular}{cccccc}
\hline Lag length & LR & FPE & AIC & SC & HQ \\
\hline 0 & NA & $4.24 \mathrm{e}-11$ & -9.69 & -9.52 & -9.62 \\
1 & 128.17 & $9.66 \mathrm{e}-12$ & -11.17 & $-10.14^{\star}$ & -10.77 \\
2 & 61.16 & $6.62 \mathrm{e}-12^{*}$ & $-11.56^{*}$ & -9.68 & $-10.82^{\star}$ \\
3 & 20.53 & $9.89 \mathrm{e}-12$ & -11.20 & -8.46 & -10.13 \\
4 & $44.02^{\star}$ & $8.20 \mathrm{e}-12$ & -11.47 & -7.87 & -10.06 \\
\hline
\end{tabular}

Table 4. Direction of variables by Granger causality test.

\begin{tabular}{c}
\hline Variables Causes Variables \\
\hline Interest $\rightarrow$ Output Gap \\
Interest $\rightarrow$ Exchange Rate \\
CPI $\rightarrow$ Exchange Rate \\
\hline
\end{tabular}

output gap. There is a causality from inflation to exchange rate; this is the situation where consumers have expectations that inflation will rise and shape their behaviors accordingly. In such an environment, the decrease in the reliance on the national currency causes an increase in the demand for foreign exchange, causing the exchange rate to rise and the national currency to further depreciate. Inflationary environments without price stability cause the exchange rate to rise.

When we look at the graphs of the results of the impulse-response analysis made in Figure 1, we can say that the effect starts after one quarter. Here, as a result of a unit deviation given as a shock, the effect of independent variables on the dependent variable CPI is seen. When we examine all the variables separately, we see that in the impulse-response analysis, which has the effect of the variables on CPI, namely inflation, we can say that inflation had a positive effect on inflation from the first period but this effect started to decrease gradually. When the effect of the output gap on the CPI is analyzed, it is seen that the output gap has a negative effect and this negative effect has increased until the third period, then it approaches to zero. As can be seen from the figure, output gap causes inflation to fall, but the effect remains very weak. The effect of oil prices on CPI has been increasing from the first period to the third period and has been continuously decreasing after the third period. When we look at the impact of the exchange rate on the CPI, the period in which the exchange rate rises causes an increase in inflation and a decrease from the third period to the fourth period, although there is a minimum increase afterwards, this effect is continuous and this effect is not long-term as shown in the figure. When we look at the effect of interest rates on the CPI, we observe an increase up to the third period, a decline from the third to the fourth period, and then an upward trend from the fourth to the fifth period, followed by a continuous but slow decline. It is seen that interest rate affects inflation more than the exchange rate does. It is seen that CPI is the most important variable that causes inflation to increase; there is an inflation inertia in Turkish economy. 
Response to Cholesky One S.D. Innovations \pm 2 S.E.

Response of TUFE to TUFE

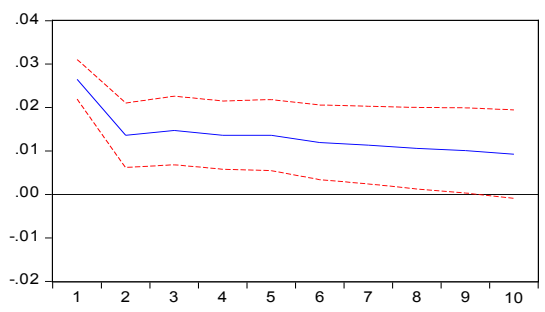

Response of TUFE to PETROL

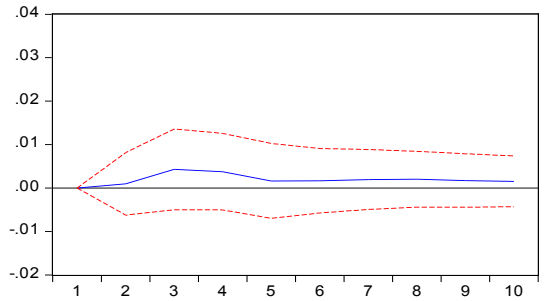

Response of TUFE to FAIZ

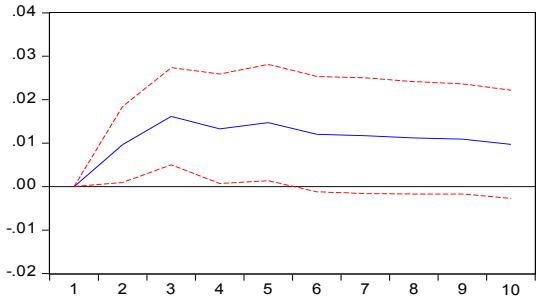

Response of TUFE to CIKTI

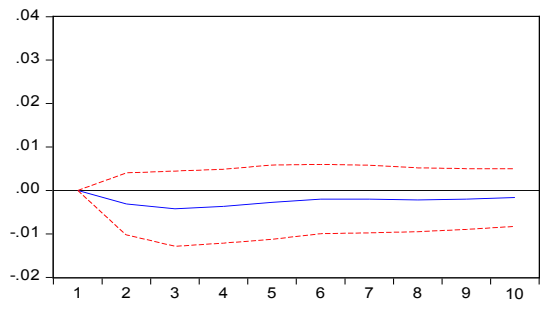

Response of TUFE to DOLAR

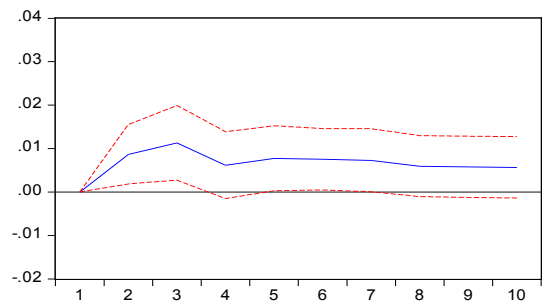

Figure 1. Effect of variables on CPI: impulse-response analysis.

The inflation rate of the previous period directly affects the inflation rate after a period. It is similar to the theory of adaptive expectations. Consumers, who have shaped their expectations over the inflation rate in the next period by looking at the inflation rate in the previous period, determine their consumption and expenditure plans accordingly, which leads to the formation of inflation. According to our deduction from these graphs, expectations and cost push inflation (due to exchange rate and interest rate), which are the causes of inflation, co-exist and this plays a role in the high rates of inflation.

In Table 5, which shows the results of variance decomposition, we see the changes in CPI as a response of the explanatory variables used in the analysis. In the table, it is seen that CPI is affected by itself the most in the rate of $83 \%$ in the second quarter. After that, it is affected by the Dollar variable, i.e. the exchange rate at $7.05 \%$, from the Interest variable with $8.78 \%$. As the impulse-response analysis shows, the effect of interest on inflation and the response of inflation entered into an upward trend in the form of a sharp increase until the third period and after the third period, this trend followed a steady increasing trend, although not in the form of a jump. As the period progresses, it is observed that the effect of CPI on itself decreased to $50.56 \%$ in the 10 th period, while the other explanatory variables that affect respectively are Interest and Dollar and their rates increase as time passes. In other words, it is possible to say that $33.84 \%$ of 
Table 5. Variance decomposition.

\begin{tabular}{ccccccc}
\hline Period & $\begin{array}{c}\text { Standard } \\
\text { Deviation }\end{array}$ & $\begin{array}{c}\text { TUFE } \\
\text { (CPI) }\end{array}$ & $\begin{array}{c}\text { CIKTI } \\
\text { (Output Gap) }\end{array}$ & $\begin{array}{c}\text { PETROL } \\
\text { (Oil Prices) }\end{array}$ & $\begin{array}{c}\text { DOLAR } \\
\text { (Exchange Rate) }\end{array}$ & $\begin{array}{c}\text { FAIZ } \\
\text { (Interest Rate) }\end{array}$ \\
\hline $\mathbf{1}$ & 0.026 & 1.000 & 0.000 & 0.000 & 0.000 & 0.000 \\
$\mathbf{2}$ & 0.032 & 83.171 & 0.907 & 0.085 & 7.054 & 8.781 \\
$\mathbf{3}$ & 0.041 & 64.582 & 1.605 & 1.127 & 11.897 & 20.787 \\
$\mathbf{4}$ & 0.046 & 60.360 & 1.907 & 1.560 & 11.278 & 24.892 \\
$\mathbf{5}$ & 0.051 & 56.549 & 1.847 & 1.377 & 11.538 & 28.687 \\
$\mathbf{6}$ & 0.054 & 54.661 & 1.762 & 1.305 & 12.082 & 30.187 \\
$\mathbf{7}$ & 0.057 & 53.147 & 1.707 & 1.291 & 12.497 & 31.355 \\
$\mathbf{8}$ & 0.059 & 52.092 & 1.704 & 1.304 & 12.497 & 32.401 \\
$\mathbf{9}$ & 0.061 & 51.194 & 1.690 & 1.291 & 12.517 & 33.305 \\
$\mathbf{1 0}$ & 0.063 & 50.568 & 1.667 & 1.279 & 12.635 & 33.849 \\
\hline
\end{tabular}

inflation is due to interest rates and $12.63 \%$ is due to the exchange rate. The effect of output and oil seems to be very low. We can say that the most intense effect is inflation itself with $50.56 \%$, but the effect of exchange rate, especially interest rate, is quite large.

Accordingly, the reason that inflation affects inflation is the expectation that the future inflation rate will increase. This gradually decreased over the periods, but this time the rise in interest rates triggered inflation. There are many reasons for the increase in interest rates, one of which is the exchange rate which causes inflation to rise, as shown in the table. The increase in the exchange rate decreases the value of the domestic currency and triggers inflation in a country whose economy is heavily dependent on foreign countries, leading to an increase in production costs, an inability to convert external borrowing debts and an increase in debt burden, resulting in lower production and an increase in prices. In order to prevent this, the central bank raises the interest rate, attracts foreign capital here and increases the amount of foreign currency and increases the value of the national currency. This interest rate hike does not cause inflation to fall due to the fact that the cost of borrowing is interest.

This case is being implemented within the framework of inflation targeting Taylor rule strategy. Especially in an environment where there is cost push inflation, inflation does not decrease as a result of the interest rate hike to reduce both inflation and exchange rate. On the contrary, interest rates increase and cause cost inflation to increase further. Interventions made using the interest rate instrument are ineffective as inflation increases due to external factors. In such an economic environment, the Taylor Rule is ineffective.

When we look at the developments that have occurred since the beginning of the inflation targeting strategy, it is seen that the interventions made with short-term interest rates had a lowering effect on inflation at the beginning, but especially the interventions made after 2010 were not functional. In the short 
term, this rule has had a positive effect, but in the long run, the effect of reducing inflation has weakened. Normally, the growth rate increases during periods of high inflation; but we see that there is a low rate of growth with high inflation, given the current economic conditions in Turkey. In such an economic environment, it is difficult to say that the Taylor Rule applied under the inflation targeting strategy is a valid policy. Text heads organize the topics on a relational, hierarchical basis. For example, the paper title is the primary text head because all subsequent material relates and elaborates on this one topic. If there are two or more sub-topics, the next level head should be used and, conversely, if there are not at least two sub-topics, then no subheads should be introduced. Styles named "Heading 1", "Heading 2", "Heading 3", and "Heading 4" are prescribed.

\section{Conclusions}

We analyzed the success of inflation targeting strategy and its interaction with macroeconomic factors through econometric analysis based on macro variables. The results show that there is structural inflation, expectation inflation and cost push inflation in the country; all these causes trigger inflation and thus, actual inflation is distanced from the target. There is also uncertainty about inflation due to the failure to reach the target value and a rising course. According to our results, it is seen that inflation targeting strategy is not a sufficient policy by itself, but this does not necessitate the abandonment of the policy. Together with the inflation targeting strategy, some other steps have to be taken to improve the conditions in order to strengthen the policy. Consistent with fiscal policy and changing the inflation expectations of public are the possible policies to support the inflation targeting policy.

As a result of the analyses, it is inflation itself that affects inflation the most in the first order. The inflation rate of the previous period directly affects the inflation rate after a period. This is similar to the theory of adaptive expectations. From this point of view, the consumers, who shaped their expectations over the inflation rate in the next period by looking at the inflation rate in the previous period, determine their consumption and expenditure orientations accordingly; in other words, expectation leads to inflation. According to our conclusion from the empirical results, expectations and cost inflation, which are the causes of inflation, co-exist and this plays a role in the high rates of inflation.

Foreign exchange loss as a result of huge foreign trade deficits creates a deterioration in exchange rates and this situation triggers the cost-push pressures in the inflation rate. Each increase in interest rates affected inflation and led to an upward trend. Multiple macroeconomic variables have an impact on the rise of inflation, and the inflation targeting strategy alone cannot be a sufficient solution to weaken these effects, leading to a failed course of the strategy; in addition to inflation targeting strategy; to produce structural reforms that will reduce the import rate and foreign exchange dependence, and to implement them strictly without compromising these policies, to develop strategies to increase the saving 
rate of the country and thus to reduce the dependence on foreign capital. Thus, the negative impact of structural inflation will possibly be eliminated. Expansionary fiscal policy should be replaced by contractionary fiscal policy until the macroeconomic situation improves and stabilizes. These are not only solutions that the CBRT can produce and implement. For this purpose, macro balances should be restored, exchange rate dependence should be reduced and serious steps should be taken for this purpose. If all of these are implemented successfully, inflation can be reduced permanently and thus the policies implemented by the CBRT will be more effective, results will be achieved faster and economic stability, price stability and desired social welfare will be achieved by providing country development and economic growth.

\section{Conflicts of Interest}

The authors declare no conflicts of interest regarding the publication of this paper.

\section{References}

[1] Akyazı, H. (2004) Enflasyon Hedeflemesi, Ülke Deneyimleri ve Türkiye'de Uygulanabilirliği. Seçkin Publishing, Ankara.

[2] Ekinci, A. (2009) Enflasyon Hedeflemesi, Büyüme ve Türkiye Cumhuriyet Merkez Bankas1. Journal of Bankers, No. 68, 3-19.

[3] Yiğit, N. (2006) Enflasyon Hedeflemesi. Unpublished MA Thesis, Ankara University Institute of Social Sciences, Ankara.

[4] Yapraklı, S. and Kaplan, F. (2012) Türkiye'de Uygulanan Açık Enflasyon Hedeflemesi Stratejisinin Başarısı Üzerine Ekonometrik Bir Değerlendirme. Journal of Faculty of Economics and Administrative Sciences Hacettepe University, 30, 185-208.

[5] Güney, P.Ö. and İbrahim, M.C. (2014) Enflasyon hedeflemesi ve Türkiye Deneyimi. Journal of Faculty of Economics and Administrative Sciences Hacettepe University, 32, 143-164. https://doi.org/10.17065/huiibf.66667

[6] Şahan, B. (2018) Enflasyon Hedeflemesi Stratejisinde Türkiye Cumhuriyet Merkez Bankası Faiz Politikasının Etkisi. Unpublished MA Thesis, Balıkesir University Institute of Social Sciences, Balıkesir.

[7] Eroğlu, İ. (2009) Enflasyon Hedeflemesi Rejimi ve Türkiye'deki Uygulamanın Performans Analizi. Unpublished MA Thesis, Marmara University Institute of Social Sciences, Marmara.

[8] Tezgör, A. (2010) Merkez Bankasının Enflasyon Hedeflemesinin Makro Ekonomik Değişkenlere Etkisi. Unpublished MA Thesis, Dumlupınar University Institute of Social Sciences, Dumlupinar.

[9] Ermişoğlu, E. (2011) Enflasyon Hedeflemesi Rejiminin Türkiye'deki Başarısının Değerlendirilmesi. Working Paper Series, Central Bank Republic of Turkey, Ankara.

[10] Erdoğan, S., Durmuş, Ç.Y. and Güneş, H. (2010) Enflasyon Hedeflemesi Stratejisi Makroekonomik Performans Üzerinde Etkili midir? Finance Journal, No. 159, 1-16.

[11] Central Bank Republic of Turkey (2002) IMF Letter of Intent. Secretary of Treasury.

[12] Central Bank Republic of Turkey (2005) Enflasyon Hedeflemesi Rejiminin Genel Çerçevesi ve 2006 Yılında Para ve Kur Politikası. Working Paper Series. 
[13] Durmuş, H. (2018) Türkiye'de Enflasyon Hedeflemesi: Örtük Enflasyon ve Açık Enflasyon Dönemleri Üzerine Bir Değerlendirme. Siirt University Journal of Social Sciences, No. 11, 181-201.

[14] Central Bank Republic of Turkey (2018) Merkez Bankası Para Politikası Çerçevesi.

[15] Alper, E.C. and Aruoba, S.B. (2001) Makroekonomik Verilerin Mevsimsellikten Arındırılması: Türkiye'deki Uygulamalı Araştırmacılara Dikkat Notu.

http://econweb.umd.edu/ webspace/aruoba/research/paper1/Alper_Aruoba_2001_ Turkish.pdf 